\section{Godt, men uten snert om aldring og oppmerksomt nærvær}

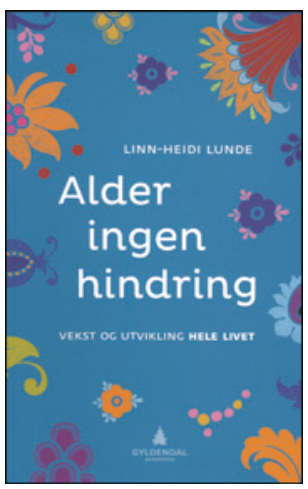

Linn-Heidi Lunde

Alder ingen hindring

Vekst og utvikling hele livet. 200 s. Oslo: Gyldendal Akademisk, 2012. Pris NOK 299 ISBN 978-82-05-42391-6

Forfatteren skriver i forordet at hun har savnet en optimistisk bok om å bli eldre, og hun henvender seg både til dem som allerede er eldre, til oss mellom 40 og 60 og gjerne også til dem som arbeider med eller omgås eldre. Hun ønsker også å bevisstgjøre leseren hvordan aldersstereotypier kan begrense livsutfoldelse og foreslår veier til bedre mestring.

Boken er lettlest, i alle fall når man har helsefaglig bakgrunn, men minner mye om en lærebok i form og oppbygging og vil derfor kunne komme til å nå færre enn intensjonen var. Oversiktlig inndelt i seks hovedkapitler der den favner bredt, men ikke særlig dypt om ulike biopsykososiale aspekter ved aldring, aldersstereotypier og oppfatninger, i tillegg til alderdommens utfordringer. Hun bruker kasuistikker for å illustrere poenger, men de er litt saktmodige og humørløse, og det er ikke alltid jeg er spent på hvordan det løser seg til slutt.

De tre første kapitlene danner et bakteppe for det jeg synes er det beste og viktigste, nemlig kapitlene om ulike mestringsmåter, og da spesielt om oppmerksomt nærvær («mindfulness»). Forfatteren formidler at ved å flytte oppmerksomhet fra «å gjøre» til «å være» kan man oppleve seg selv som del av en større helhet. På en fin måte presenterer hun hvordan dette gir mening også i lys av andre teorier om utvikling i alderdommen, som kontemplasjon og gerotranscendens, der det å fordype seg i seg selv og endre perspektiv i livet står sentralt. I denne delen er det absolutt mye optimisme og flere konkrete råd, som frister til utprøving både på egne og andres vegne.

Lunde skriver også interessant om alderisme - definert som endret oppfatning, følelse eller atferd overfor et individ pga. dets kronologiske alder. Hun viser hvordan integrerte, oftest negative og ubevisste holdninger til eldre og aldring (aldersstereotypier) lett kan bli selvoppfyllende profetier fordi vi tar dem med oss inn i egen alderdom. På denne måten er vi alle med på å svekke eldres innflytelse og legge hindre i veien for god kontakt på tvers av generasjoner.

Hun presenterer oppmerksomt nærvær som en hensiktsmessig, ja, til og med attraktiv metode for best mulig å møte egen aldring. Men som nevnt innledningsvis, tror jeg dessverre lærebokformen gjør at bare de som allerede er litt over middels interessert, finner frem, og at gjennomslagskraften blir større når respekterte, eldre «kjendiser» formidler det samme: nemlig at det ofte handler mye mer om hvordan du tar det enn hvordan du har det!

Marte Mellingsæter

Geriatrisk avdeling

Oslo universitetssykehus

\section{Omfattende om menn som har vært utsatt for seksuelle overgrep}

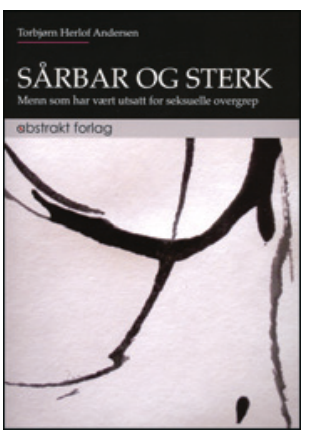

\author{
Torbjørn Herlof Andersen \\ Sårbar og sterk
}

Menn som har vært utsatt for seksuelle overgrep. 195 s, ill. Oslo: Abstrakt forlag, 2012. Pris NOK 275

ISBN 978-82-7935-338-6

Forfatteren skriver i forordet at «Denne boken vil jeg tilegne de mennene som har vist meg at styrke og svakhet kan forstås på helt andre måter enn det som er vanlig». Videre i samme forord står det: «Mitt ønske er at det jeg videreformidler på disse sidene kan bidra til at flere opplever at det angår dem.»

Torbjørn Herlof Andersen er ansatt som amanuensis ved Høgskolen i Gjøvik, og boken bygger på forfatterens doktoravhandling i sosialt arbeid. Den har 15 kapitler, og hovedintensjonen er å belyse ett av de kanskje mest tabubelagte temaene som finnes, nemlig menn som har vært utsatt for seksuelle overgrep.

Grunnlaget er fortellinger fra menn i alderen 20-75 år som i ung alder ble utsatt for overgrep. Forfatteren presenterer, slik han selv sier, en oppsummering av mer enn 14 års engasjement innen overgrepsfeltet. Analysen er basert på fortellinger, samtaler og kvalitative intervjuer av 15 menn, hvorav dybdeintervjuer eller fortellinger fra fire menn utgjør hovedpresentasjonen. I fortellingene beskriver forfatteren opplevelsene de utsatte mennene har av at en annen person har utnyttet deres maktunderskudd til egen tilfredsstillelse. $\AA ̊$ ha vært utsatt for seksuelle overgrep har i seg selv store skadevirkninger. Mennene forteller imidlertid også om den ekstra skammen de opplever på grunn av rådende, generelle mannlighetsoppfatninger. Dette forsterker skam- og skyldfølelsen knyttet til selve overgrepet.

Forfatteren sier at tap av kontroll leder til opplevelse av verdiløshet, selvanklagelser og skam, og beskriver hvordan skyld og skam forsterkes av eksisterende mannlighetskodeks. Hemmelighold av overgrepene er felles for de intervjuede mennene, og det er i møte med forfatteren at de for første gang forteller omverden om hendelsene. Åpenhet og det å kunne fortelle om overgrepene har i stor grad hjulpet mennene til å gjenvinne kontroll, verdi og verdighet.

Andersen har gjort et viktig stykke arbeid om et tema som er lite omtalt, og som sjelden kommer frem i legers møter med pasienter. Det er derfor synd at ikke forlaget har lagt større vekt på å presentere det viktige materialet på en god måte. Etter min oppfatning er boken ordrik med til dels lange akademiske diskurser, og for omfattende med en rekke gjentakelser. Språket er til dels vanskelig og lite direkte. Mange leger vil nok derfor kunne oppleve den som til dels kjedelig og lite tilgjengelig.

Nyttig kunnskap om et så viktig tema - menn som har vært utsatt for overgrep og beskrivelser av konsekvenser dette har for deres videre liv og samliv - fortjener å bli tilgjengeliggjort for mange. Jeg mener at teksten dessverre ikke overholder forfatterens ønske om å «angå» leseren. Forlaget burde gjort mer med både fremstillingsformen og formidlingen.

Haakon Aars

Institutt for klinisk sexologi og terapi

Oslo 